Annals of Warsaw University of Life Sciences - SGGW

Land Reclamation No 43 (1), 2011: 13-23

(Ann. Warsaw Univ. of Life Sci. - SGGW, Land Reclam. 43 (1), 2011)

\title{
Ground water fed system restoration on the area of Przemkowsko- -Przeclawskie Wetlands
}

\author{
ANDRZEJ BRANDYK \\ Department of Water and Soil Science, Warsaw University of Life Sciences - SGGW
}

\begin{abstract}
Ground water fed system restoration on the area of Przemkowsko-Przectawskie Wetlands. The aim of the paper is the estimation of hydrological conditions occurring on the area of Przemkowsko-Przecławskie Wetlands in the proposed water management scenarios, which are implemented to restore natural values of the wetland environment. In each of the scenarios, the operation parameters of hydraulic structures were changed, causing the potential increase of ground water alimentation to the wetland area. Common and recognized ground water flow model MODFLOW was used to calculate ground water levels for each scenario and to study the long-term effect of restoration measures on Przemkowsko-Przecławskie Wetlands. Following hydrological characteristics were analysed: mean of the mean ground water levels, inundation frequency, mean ground water amplitude and mean low ground water levels. These characteristics were modeled for the long-term period 1964-1985 for unsteady flow conditions and were compared with the values adopted from intact, reference wetlands. It was proved, that slowing down the outflow of ground water (scenario 1) didn't provide hydrological conditions desired for the maintenance of swampy habitats. The combination of outflow slow down and restriction of ground water abstraction by existing pumping stations (scenario 2 ) didn't guarantee the maintenance of desired values of hydrological characteristics for a swampy habitat as well. The realization of the proposed scenarios enables to keep proper conditions for wet and moist habitats. The management policy for Przemkowsko-Przeclawskie Wetlands should then be directed at the development of those habitats, providing broad realization of environmental protection goals.
\end{abstract}

Key words: Wetlands restoration, hydrological characteristics, ground water flow modeling, water management scenarios, habitat types.

\section{INTRODUCTION}

At present, natural environment of many wetland areas has been transformed in a large extent, due to changes of hydrological conditions and because of varying management of those areas (Ilnicki 2002). In order to cease transformation of wetlands environment, restoration measures have been applied. These measures involve such water management, that enables restoration of hydrological conditions, and they also include the combination of pasture and meadow management, which helps to keep and upgrade the ecological status of plant communities. (Brandyk et al. 2005). For restoration purposes, water management scenarios are elaborated in order to find out ways of restoring hydrological alimentation that existed in the past on the wetland area. In the contemporary times, the analysis of such scenarios requires hydrological modeling of ground water flow. The application of ground water flow models provides knowledge on the dynamics of ground water levels for the analysed water management scenarios, which helps to select such management 
option that sufficiently meets the requirements of the restoration, or at least allows to implement a compromise solution for the area, on which the wetland restoration is considered in the management plans.

In the middle Basin of the Biebrza River in Poland, hydrological characteristics of ground water levels were analysed for 9 proposed water management scenarios basing on modeling results. It enabled to evaluate the surface of potentially swampy areas for all the scenarios, as a result of changes in the rules of hydrographic system operation. (Okruszko 2005). Many of the areas located close to the main channels in the Middle Biebrza Basin were subject to a significant rise in ground water levels, suitable to maintain a wetland, as it was concluded basing on the results of modeling.

Mioduszewski et al. (2004) applied the ground water flow model SIMGRO (Querner et al. 2000) to determine zones in the Lower Biebrza Basin of a different hydrological alimentation type. The determination of those zones enabled to outline recommendations for water management in the Lower Biebrza Ba$\sin$. The need for constructing weirs in small steams and tributaries to Biebrza was stressed and also the maintenance of an extensive use of the Biebrza Uplands was emphasized, because those uplands are the areas of rainfall water infiltration which then recharges the valley wetlands as ground water.

Applying restoration measures for different wetland areas in Europe has provided generally a satisfactory quality of restored wetland vegetation, however the phytosociological dynamics of that vegetation was estimated to be high (Aa- pala and Tukia 2008). The restoration and the use of retention capabilities of wetlands was as well satisfactory (Duel and Penning 2004), however, for a near future, a decreasing trend of ground water levels has been forecast for wetland areas (Brown 2008; Dietrich et al. 2008). If possible, the use of surface water for restoration should be considered, however, the problem of surface water quality still needs to be resolved ( Brandyk et al. 2005).

Boswell et al. (2007) and Dietrich et al. (2008) use ground water modeling to show that the restoration of wetlands with the use of ground water recharge is possible, when the surface of the restoration area is very limited. Thompson et al. (2004) basing on ground water modeling results, consider the possibilities to regain wet meadow habitats instead of swampy habitats, with mean ground water levels maintained at the depth of 0.3 to $0.5 \mathrm{~m}$, below ground surface.

The analyses, carried out by applying ground water modeling, indicated, that the restoration of hydrological conditions of wetlands with the use of ground water resources only is difficult, and possible by large limitation of the surface of restoration areas or by increasing the quantity of water used for restoration (Schrautzer et al. 1996). However, the use of ground water only for restoration of wetlands is usually justified on account of the quality of that water (Cieślak et al. 1999).

For the restoration area of Przemkowso-Przecławskie Wetlands, the ground water is recommended to be used, since surface water reserves are limited and are widely used to cover economical needs. (Brandyk et. al 2005; Grootjans et al. 2007). Also the quality of surface water 
is estimated to be inappropriate (Cieślak et al. 1999) So, for the development of a ground water fed system within the area of Przemkowsko-Przecławskie Wetlands, rules for water management should be elaborated and analysed with the use of ground water flow model, followed by the evaluation of the potential type of restored habitats determined by changes of ground water levels.

\section{MATERIAL AND METHODS}

Przemkowsko-Przecławskie Wetlands, which cover the total area of 3050 ha, are located in the south-western Poland in the Lower Silesia, within the catchment of the Szprotawa River (Brandyk et al. 2005) (Fig. 1). They form an exceptional and interrelated complex of wetlands with many unique species of flora. Most valuable are: reed communities and wet meadows with willow shrubs, small areas of fens and alder carr on parts of the system, shallow, eutrophic water reservoirs as well as sedge communities and stands of molinia coruleae. The vegetation patterns of Przemkowsko-Przecławskie Wetlands have been disturbed in last decades, and nowadays new management solutions are implemented, with the consideration to what extent the natural values of wetland vegetation may be restored by introducing changes in the water management system. The modeling studies are now envisaged to find out such changes of hydraulic structures operation that will enable increased ground water recharge to Przemkowsko-Przecławskie Wetlands. The inflowing ground water is estimated to be of a satisfactory quality and will not cause eutrophication of the wetland vegetation (Brandyk et. al 2005; Grootjans et al. 2007).

For the increase of the recharge of ground water to Przemkowsko-Przecławskie Wetlands, following water management scenarios were elaborated.

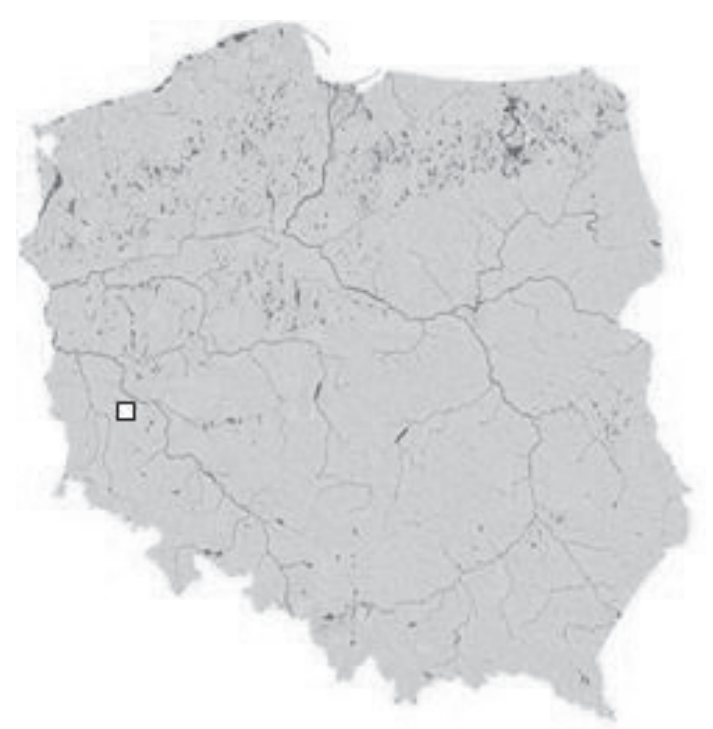

FIGURE 1. Location of Przemkowsko-Przecławskie Wetlands on the map of Poland 
0. Existing situation: operating drainage canals and ground water pumping station working, this scenario is assumed to be a reference one.

1. Blocked outflow: maximum rise of water levels in drainage canals for restricting their dewatering impact, pumping stations switched on;

2. Maximum rise of water levels in drainage canals and pumping switched off (Fig. 2).

The answer, if the analysed scenarios exert a desired effect on ground water levels, required modeling of ground water flow, aggregating the results on a GIS platform, evaluating the magnitude of changes in ground water table position against the threshold values of ground water table for the assumed hydrological criteria. These analyses were not performed for the whole wetland area. On account of agricultural and administrative issues, the potential restoration area was determined to be approximately $57 \%$ of the primary wetland, that is 1760 ha out of 3050 ha. The threshold values of ground water levels were adopted from studies carried out for the natural wetlands in the Biebrza Valley in Poland (Mioduszewski et al. 1996). Modeling results were compared with these values, which enabled estimation of hydrological conditions for new, potential habitats on the restoration area. According to the studies for the Biebrza Valley, the habitats were divided into three categories (Okruszko 2005):

1. Swampy habitats, characterized by the presence of sedge-moss communities, reed communities and tall-sedge communities;

2. Wet habitats, containing mosaic of herb communities (Oświt 1991);

3. Moist habitats, situated on extensively used grasslands. Hydrological characteristics, used to distinguish habitat types on the restoration area, are given in Table 1.

Ground water levels on the area of Przemkowsko-Przecławskie Wetlands

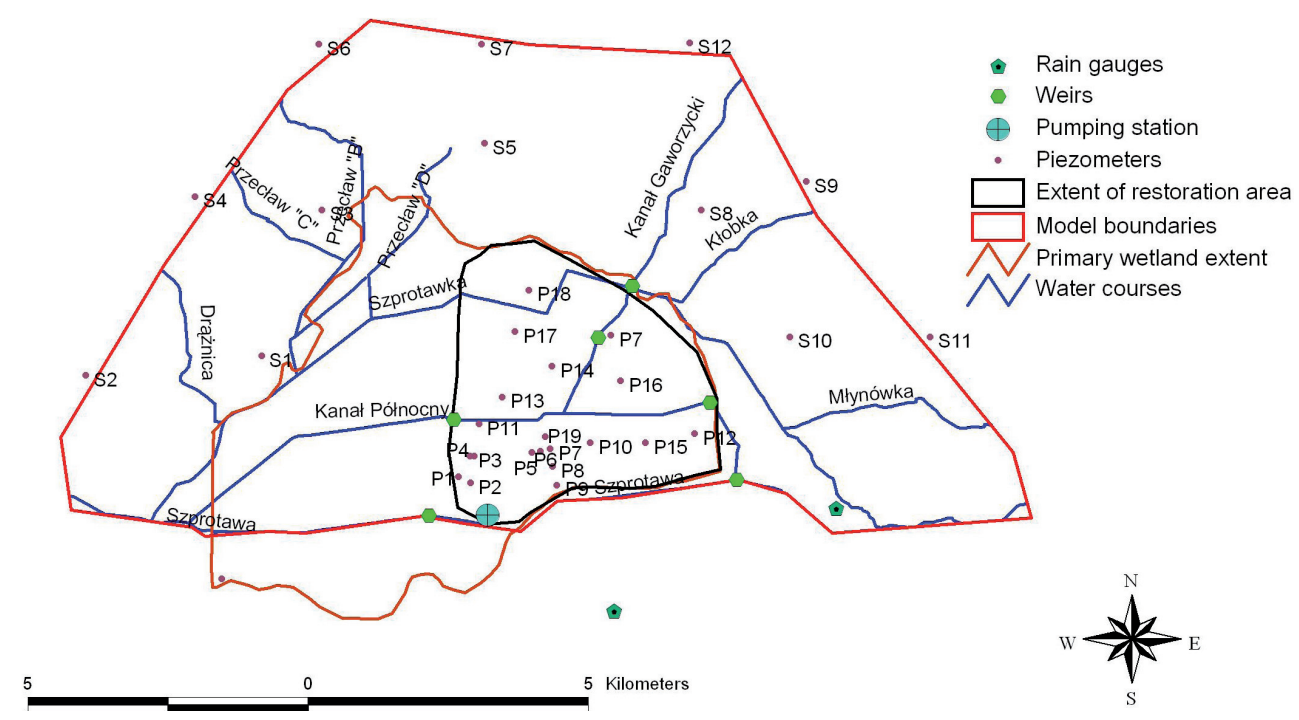

FIGURE 2. Hydrographic network of Przemkowsko-Przecławskie Wetlands 
TABLE 1. Threshold values of hydrological characteristics for habitat wetness classification (Okruszko 2005)

\begin{tabular}{|l|c|c|c|c|}
\hline Habitat type & MMGL [m] & IF \% & MGA [m] & MLGL [m] \\
\hline $\begin{array}{l}\text { Swampy habitats of } \\
\text { a low ground water } \\
\text { amplitude }\end{array}$ & $>0$ & $>30$ & $<-0.7$ & \\
\cline { 1 - 1 } $\begin{array}{l}\text { Swampy habitats of } \\
\text { a high ground water } \\
\text { amplitude }\end{array}$ & & & $>-0.7$ & \\
\cline { 1 - 4 } Wet habitats & $<-0.3 ; 0>0.6$ & $<10 ; 30>$ & - & - \\
\hline Moist hsbitats & $<-0.6 ;-0.3>$ & $<10$ & - & - \\
\hline
\end{tabular}

Explenation:

MMGL - mean of the mean ground water levels;

IF - inundation frequency;

MGA - mean ground water amplitude;

MLGL - mean low ground water levels.

were calculated with the use of a common ground water flow model MODFLOW (McDonald et al. 1988). This model enables to solve partial differential equation of saturated ground water flow, by discretizing the saturated ground water regime into a number of computational cells for which water mass conservation is realized. The cells are arranged in rows, columns and layers. In plan view, the analysed system was discretized with cells of a uniform size: 100 by $100 \mathrm{~m}$, giving 406 rows and 217 columns. The stratigraphy of the analysed area was represented by the appropriate number of model layers. Model layers are assigned to main hydro-stratigraphic units (Brandyk 2010). For Przemkowsko-Przecławskie Wetlands a two-layer model was built with the first layer representing shallow ground water unit in sands, peat and loamy sands. The second model layer represented deep, regional ground water table of a sandy aquifer. The hydraulic contacts between layers were represented as vertical leakance term (Brandyk 2010). The geometry of layers was represented by properly set dimesions of the model grid, basing on existing boreholes and geological crosssections. After setting the model grid, the identification of model parameters was performed and the proper boundary conditions of the model were applied (Brandyk 2010). Laboratory and field tests were completed to identify hydraulic conductivities of model layers and the conductivities of riverbed materials (Brandyk 2010). The data for rainfall and evapotranspiration estimation were collected from nearby weather stations. The influence of rainfall and evapotranspiration on ground water levles was reflected by applying appropriate, positive or negative recharge flux values for the upper model layer. Next, the parameter values were calibrated and validated against the observed ground water levels. After the calibration, the model was used to simulate long-term ground water flow on the area of Przemkowsko-Przecławskie Wetlands in all assumed water management scenarios. The results of modeling enabled to estimate the possibilities and 
constrains to the restoration of swampy habitats on the area of the wetlands.

\section{RESULTS AND DISCUSSION}

The calibration was the trial-and-error procedure to fit the parameter values in order to reach a reasonable match between the observed and the calculated ground water levels for the year 2004. Following model parameters were calibrated: hydraulic conductivities for the first and the second model layer, the conductance of riverbeds, vertical leakance between layers and potential evapotranspiration rates for reed communities. Each parameter was calibrated individually. The model was run with varying value of one, single parameter while other parameters remained unchanged. There were about 50 model runs for one parameter, and after each run the discrepancies between the model and observation were assessed by calculating 5 error values (C1-C5), so called Nash-Sutcliffe-Efficiency (Liu et al. 2004). Mean values of model errors for the calibration period are presented in Table 2.

TABLE 2. Mean error values for the calibration period

\begin{tabular}{|l|c|c|c|c|c|}
\hline Error & $\mathrm{C} 1$ & $\mathrm{C} 2$ & $\mathrm{C} 3$ & $\mathrm{C} 4$ & $\mathrm{C} 5$ \\
\hline Mean value & 0.12 & 0.71 & 0.72 & 0.72 & 0.83 \\
\hline Optimum & 0 & 1 & 1 & 1 & 1 \\
\hline
\end{tabular}

Years 2005-2007 were selected to be the validation period. The model was run with the calibrated parameter values for that period. Next, the quality of model performance was estimated by calculating following error values (Tab. $3 a$ and b): mean error, mean absolute error,

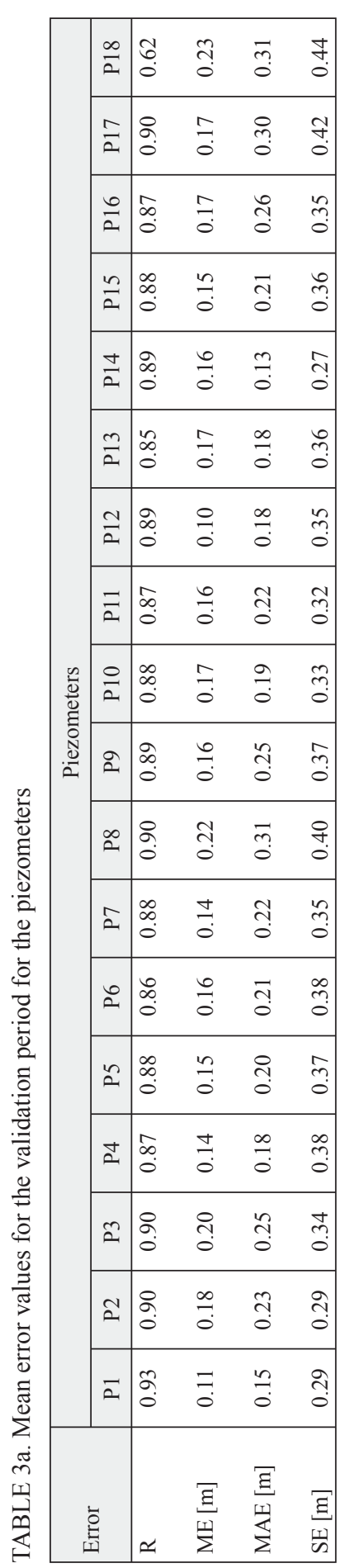


TABLE 3b. Mean error values for the validation period for the wells

\begin{tabular}{|c|c|c|c|c|}
\hline \multicolumn{5}{|c|}{ Wells } \\
\hline S1 & S3 & S5 & S8 & S10 \\
\hline 0.87 & 0.8 & 0.75 & 0.69 & 0.68 \\
0.19 & 0.18 & 0.24 & 0.19 & 0.17 \\
0.26 & 0.28 & 0.34 & 0.27 & 0.23 \\
0.34 & 0.32 & 0.43 & 0.35 & 0.36 \\
\hline
\end{tabular}

standard error and the correlation coefficients for the observed and calculated hydraulic heads. (Brandyk 2010):

Moreover, the correlation diagrams were constructed for all observation wells. Figures 3 and 4 show exemplary diagrams for wells $\mathrm{P} 2$ and $\mathrm{P} 6$.

The slope of the analysed linear correlation functions is close to 1 (the angle between the function and the $\mathrm{x}$-axis is nearly 45 degrees) which proves a close match between the model and the observation, which is also proved by error values (Tab. 3a, b).

The stage of model calibration was followed by model exploitation. At that stage the model was used to simulate ground water levels for the analysed water management scenarios. The simulation was performed for unsteady flow conditions for the period 1964-1988. As a result of modeling, the characteristic ground water levels were calculated and compared with assumed threshold values (Tab. 1). On the basis of those calculations, the estimation of hydrological conditions was performed for the new, potential habitats that will occur on the restoration area in consequence of an increased ground water recharge.

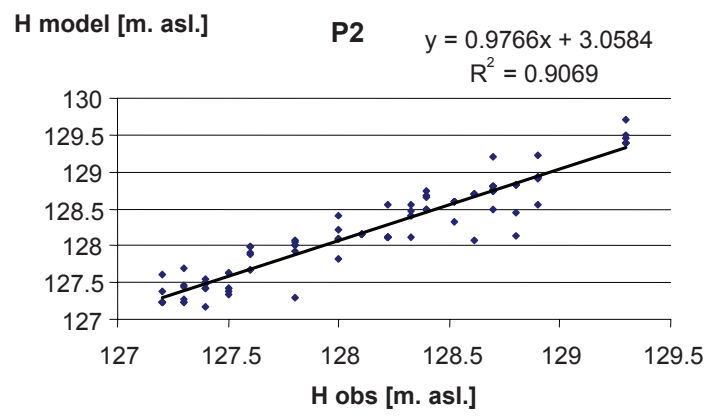

FIGURE 3. Correlation diagram for piezometer P2

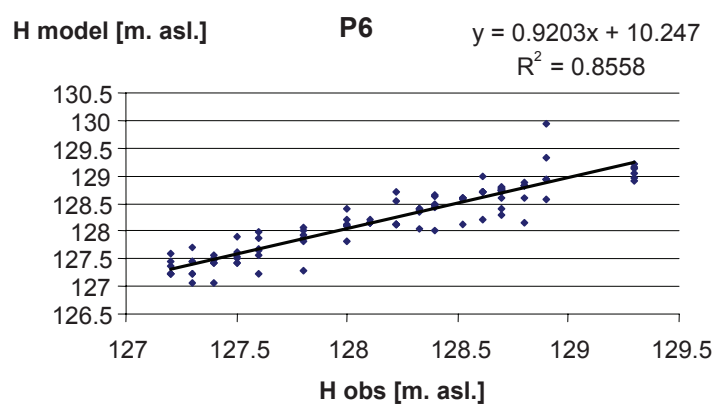

FIGURE 4. Correlation diagram for piezometer P6 
Figure 5 presents mean long-term ground water levels for individual restoration scenarios. Their values enable to distinguish those areas, where hydrological conditions contribute to the development of swamp habitats, and areas of sufficient hydrological conditions for the habitats of moist meadows and pastures. Mean, long-term ground water levels were presented as depths beneath ground surface.
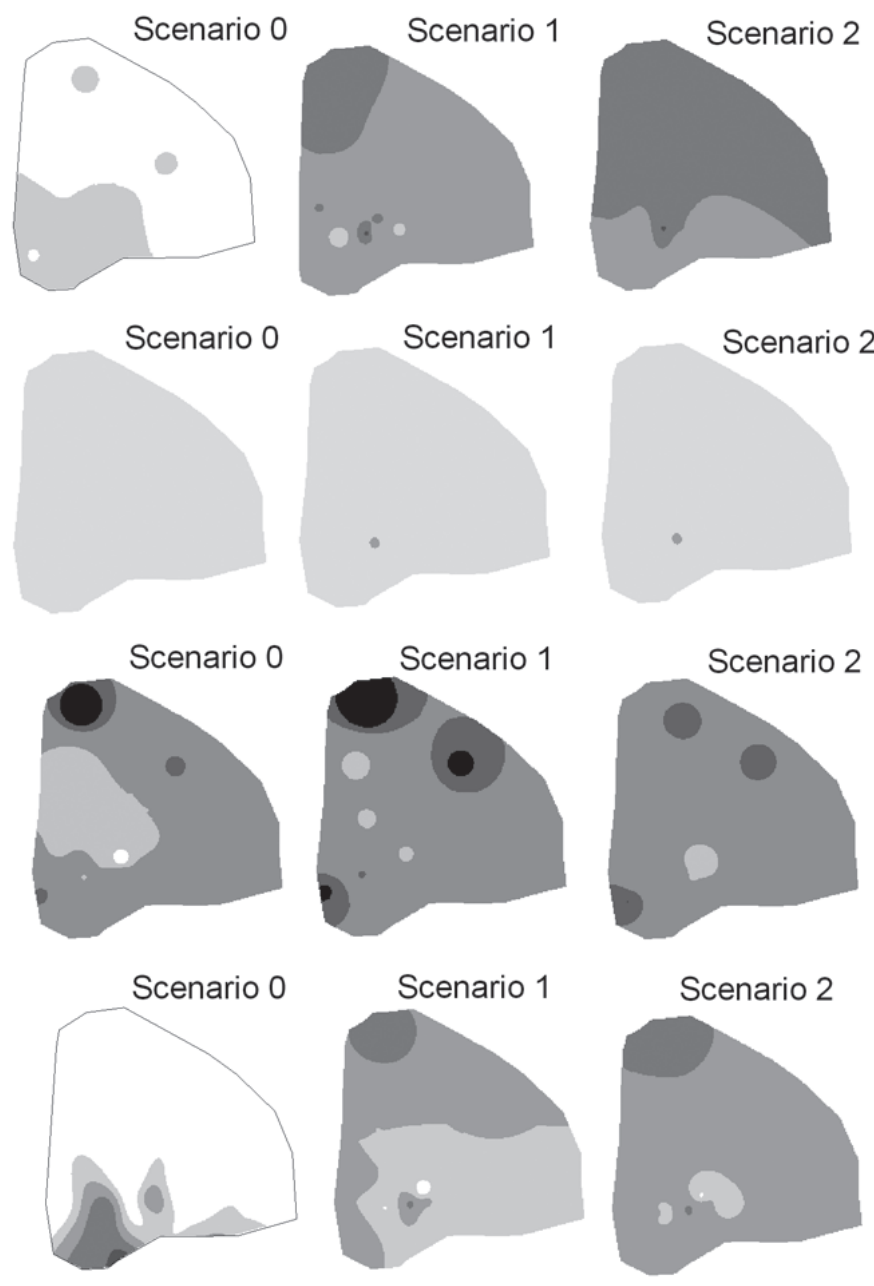

In the scenario , 0 ", that reflects current water management on the area of Przemkowsko-Przecławskie Wetlands, the mean ground water levels were maintained at the depth form 0.6 to $1.2 \mathrm{~m}$. Slowing down the outflow of ground water in scenario 1 causes the mean ground water levels to reach the depth of 0.2 to $0.6 \mathrm{~m}$, while in scenario 2 , by restricting the ground water pumping, the mean ground water levels are within the
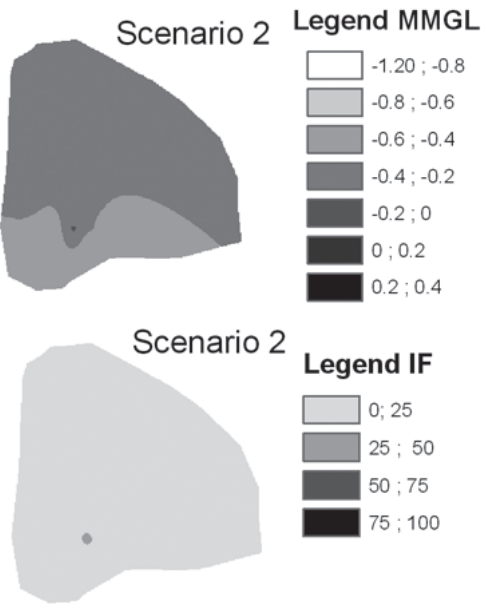

Legend IF

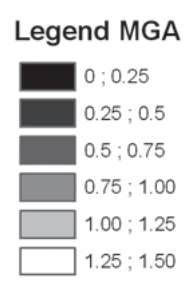

Legend MLGL

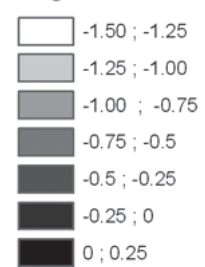

FIGURE 5. Hydrological characteristics for the analysed water management scenarios 
depth of: $0.2-0.4 \mathrm{~m}$ beneath ground surface.

The next stage of analyses focused on mean inundation frequencies of the restoration site, as the parameter that determines the formation of swampy habitats, especially related with reed and rushes communities (Fig. 5). The calculated inundation frequencies didn't exceed 25\% for the reference ("0") scenario and also for scenarios concerning slowing down the outflow and restriction of pumping.

Figure 5 also presents ground water amplitudes. The values of the amplitude distinguish the habitats with respect to alimentation heterogenity. The amplitude values ranged from $1.25 \mathrm{~m}$ to $0.5 \mathrm{~m}$ without significant differences between scenarios.

Slowing down the outflow and the limitation of ground water pumping caused also the mean low ground water levels to reach the depths from 1.5 to 0.75 (Fig. 5).

In the next stage of analyses, the calculated values of hydrological characteristics were compared with assumed threshold values (Tab. 1). As a result, the map of areas occupied by a certain habitat type was created. The map indicates the surfaces on which the changes of hydrological conditions will take place, contributing to the formation of potential habitats of a certain wetness category (Fig. 6).

The values of hydrological characteristics for an existing management (Scenario „0") are insufficient for increasing the wetness of the analysed area. The use of additional ground water recharge (scenarios 1 and 2) contributes to the development of moist and wet habitats, with the potential domination of mosaic of herb communities on extensively used grasslands.

\section{CONCLUSIONS}

Actual conditions and operation of the hydrographic system of the analysed wetlands creates inappropriate hydrological conditions for the maintenance and the development of swampy habitats. The desired water conditions for the development of wet and moist habitats are not reached as well. This situation seems to be caused by a considerable loss of ground water through drainage channels and pumping stations.

The blocking of ground water outflow provides the values of hydrological char-

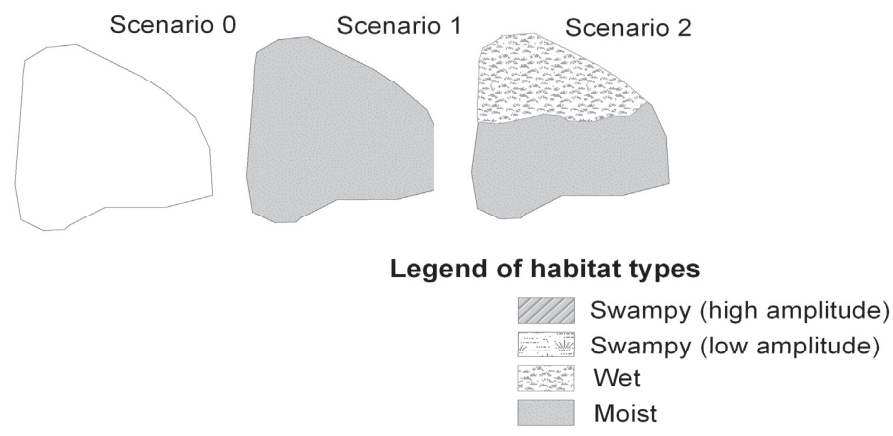

FIGURE 6. Habitats distribution on the restoration area of Przemkowsko-Przecławskie Wetlands 
acteristics proper for the development of moist habitats, and still cannot guarantee the conditions for swampy habitats. Additional restriction of ground water abstraction leads to the appearance of hydrological conditions for wet habitats, but again the area wetness doesn't reach the degree desired for the occurrence of swamp-forming processes on the protected area.

The analysis of hydrological characteristics indicated that restoration of wet habitats requires to introduce the combination of actions, involving the slowing down of the ground water outflow and completely eliminating the pumping rate of ground water wells. In this way the inflow of ground water is gradually increased, leading at first to the conditions for moist habitats, and then providing proper hydrological characteristics for wet ones.

The modeling discovers that the changes in the hydrographic system operation cause the transformation of wetland habitats. The analysis of the modeled characteristics of ground water levels helps to select both: the magnitude of the surface and the intensity of the restoration process.

\section{Acknowledgement}

The research on the restoration of Przemkowsko-Przecławskie Wetlands ground water feeding was performed with the use of the equipment of the Drainage and Irrigation Laboratory of the Water Center at WULS.

\section{REFERENCES}

AAPALA K., TUKIA H. 2008: Restoration as a tool to improve the quality of drained spruce mires in conservation areas. Proc. of the 13th International Peat Congress, published by International Peat Society.

BOSWELL J., OLYPHANT M., GREG A. 2007: Modeling the hydrologic response of groundwater dominated wetlands to transient boundary conditions: Implications for wetland restoration. Journal of Hydrology, 2007.

BRANDYK A. 2010: Modelowanie warunków wodnych na potrzeby renaturyzacji Bagien Przemkowsko- Przecławskich, rozprawa doktorska, WIKŚ SGGW [Modeling of hydrological conditions for the restoration of Przemkowsko-Przecławskie Wetlands].

BRANDYK A., SZPORAK S., OKRUSZKO T. 2005: Przemkow Landscape Park-key issues in wetlands restoration and management. Center of Excellence in Wetlands Hydrology. WAU Press.

BROWN A. 2008: Ecology of a peat bog Proc. of the 13th International Peat Congress, published by International Peat Society.

CIEŚLAK M., WOŁEJKO L., STAŃKO R. 1999: Koncepcja zintegrowanego monitoringu środowiska „Bagien Przemkowsko-Przecławskich". [The concept of the integrated monitoring of Przemkowsko-Przecławskie Wetlands] Klub Przyrodników, Szczecin, Świebodzin.

DIETRICH O., SCHWEIGERT S., STEIDL J. 2008: Impact of climate change on the water balance of fen wetlands in the Elbe Lowland. Proc. of the 13th International Peat Congress, published by International Peat Society.

DUEL H., PENNING E. 2004: Water storage: new solutions for water surplus and shortage in a small engineered country. Ecoflood, WAU Press.

GROOTJANS A., WOŁEJKO L. 2007: Conservation of mires in polish agricultural landscapes. Wydawnictwo Zachodniopomorskiego Uniewersytetu Technologicznego w Szczecinie.

ILNICKI P. 2002: Torfowiska i torf. [Peatlands and peat] Wydawnictwo Akademii 
Rolniczej im. Augusta Cieszkowskiego w Poznaniu.

LIU Y., DE SMEDT F. 2004: A GIS - based Hydrologic Model for Flood Prediction and Watershed Management. Documentation and User Manual. Department of Hydrology and Hydarulic Engineering, Vrije Universiteit Brussel, Belgium

McDONALD M., HARBAUGH W. 1988: A modular three - dimensional finite difference groundwater flow model. United States Geological Survey, Openfile Report No. 6.

MIODUSZEWSKI W., QUERNER E., ŚLESICKA A. 2004: Modelling of hydrological system of the Biebrza Valley. "Wethydro", Wyd. SGGW.

OKRUSZKO T. 2005: Kryteria hydrologiczne w ochronie mokradeł.[Hydrological criteria in wetlands protection] Rozpr. hab. Rozprawy Naukowe i Monografie. Wydawnictwo SGGW.

OŚWIT J. 1991: Roślinność i siedliska zabagnionych dolin rzecznych na tle warunków wodnych. Rocz. Nauk Rol., Ser. D, monografie.

QUERNER E., ŚLESICKA A., MIODUSZEWSKI W. 2000: Water management in the Central Biebrza Basin (Gospodarka wodna w środkowym basenie Biebrzy). Proc. of the Int. Conf. "Agricultural Effects on Ground and Surface Waters".

SCHRAUTZER J., ASSHOFF M., MULLER F. 1996: Restoration strategies for wet grasslands in Northern Germany. Ecological Engineering 7.

THOMPSON J.R., SØRENSON H.R., GAVIN H., REFSGAARD A. 2004: Application of the coupled MIKE SHE/ MIKE 11 modelling system to a lowland wet grassland in southeast England Journal of Hydrology Volume: 293, Issue: $1-4$.
Streszczenie: Renaturyzacja systemu mokradet zasilanych podziemnie na obszarze Bagien Przemkowsko-Przecławskich. W pracy wykorzystano modelowanie przepływu wód podziemnych do obliczenia charakterystyk hydrologicznych wód podziemnych na renaturyzowanym obszarze Bagien Przemkowsko-Przecławskich, dla różnych wariantów gospodarowania wodą. Analizowane charakterystyki hydrologiczne obejmowały: średnie stany wody, średnie amplitudy zwierciadła wody, częstotliwości zalewu oraz średnie stany niskie. Ich wartości uzyskano dla wieloletniego okresu 1964-1985 drogą modelowania nieustalonego przepływu wód podziemnych, a następnie porównano je $\mathrm{z}$ wartościami charakterystyk dla mokradeł referencyjnych. Na podstawie tego porównania stwierdzono, że w granicach obiektu badań odtwarzane siedliska odznaczały się warunkami wodnymi, korzystnymi dla podmokłych łąk z dominacją ziołorośli i zbiorowisk kaczeńcowych. Warunki takie uzyskano w wariantach gospodarowania wodą, zakładających kombinację spowolnienia odpływu przez urządzenia piętrzące $\mathrm{z}$ ograniczeniem ujmowania wód istniejącymi przepompowniami. W wyniku kombinacji takich działań zasilanie podziemne obiektu zwiększa się, stwarzając warunki wodne korzystne dla siedlisk podmokłych i wilgotnych, natomiast nie gwarantuje odtworzenia procesów bagiennych na obszarach chronionych.

MS. received April 2011
Author's address:
Andrzej Brandyk
Katedra Kształtowania Środowiska
Szkoła Główna Gospodarstwa Wiejskiego
ul. Nowoursynowska 159
02-776 Warszawa
A.Brandyk@levis.sggw.pl 